
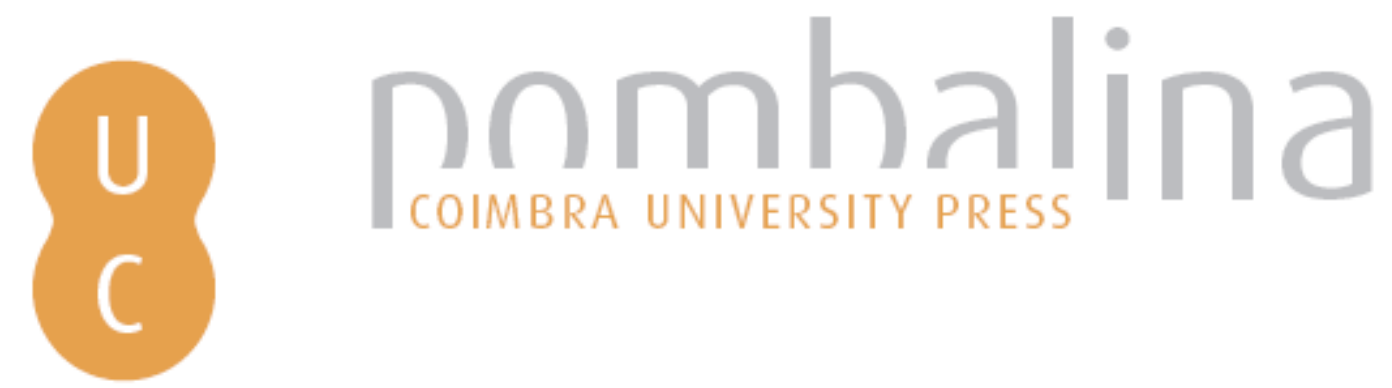

\title{
Domestic violence and forensic assessment: a multidisciplinary network perspective on the doma in of psychological violence in conjugality: part 2
}
Autor(es):
Redondo, J.
Publicado por: Imprensa da Universidade de Coimbra; International Academy of Legal Medicine
persistente:
DOI: $\quad$ DOI:http://dx.doi.org/10.14195/978-989-26-0173-1_41
Accessed : $\quad$ 26-Apr-2023 09:53:30

A navegação consulta e descarregamento dos títulos inseridos nas Bibliotecas Digitais UC Digitalis, UC Pombalina e UC Impactum, pressupõem a aceitação plena e sem reservas dos Termos e Condições de Uso destas Bibliotecas Digitais, disponíveis em https://digitalis.uc.pt/pt-pt/termos.

Conforme exposto nos referidos Termos e Condições de Uso, o descarregamento de títulos de acesso restrito requer uma licença válida de autorização devendo o utilizador aceder ao(s) documento(s) a partir de um endereço de IP da instituição detentora da supramencionada licença.

Ao utilizador é apenas permitido o descarregamento para uso pessoal, pelo que o emprego do(s) título(s) descarregado(s) para outro fim, designadamente comercial, carece de autorização do respetivo autor ou editor da obra.

Na medida em que todas as obras da UC Digitalis se encontram protegidas pelo Código do Direito de Autor e Direitos Conexos e demais legislação aplicável, toda a cópia, parcial ou total, deste documento, nos casos em que é legalmente admitida, deverá conter ou fazer-se acompanhar por este aviso.

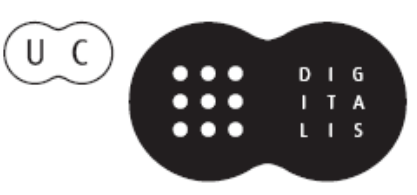




\section{Duarte Nuno Vieira Anthony Busuttil \\ Denis Cusack • Philip Beth}
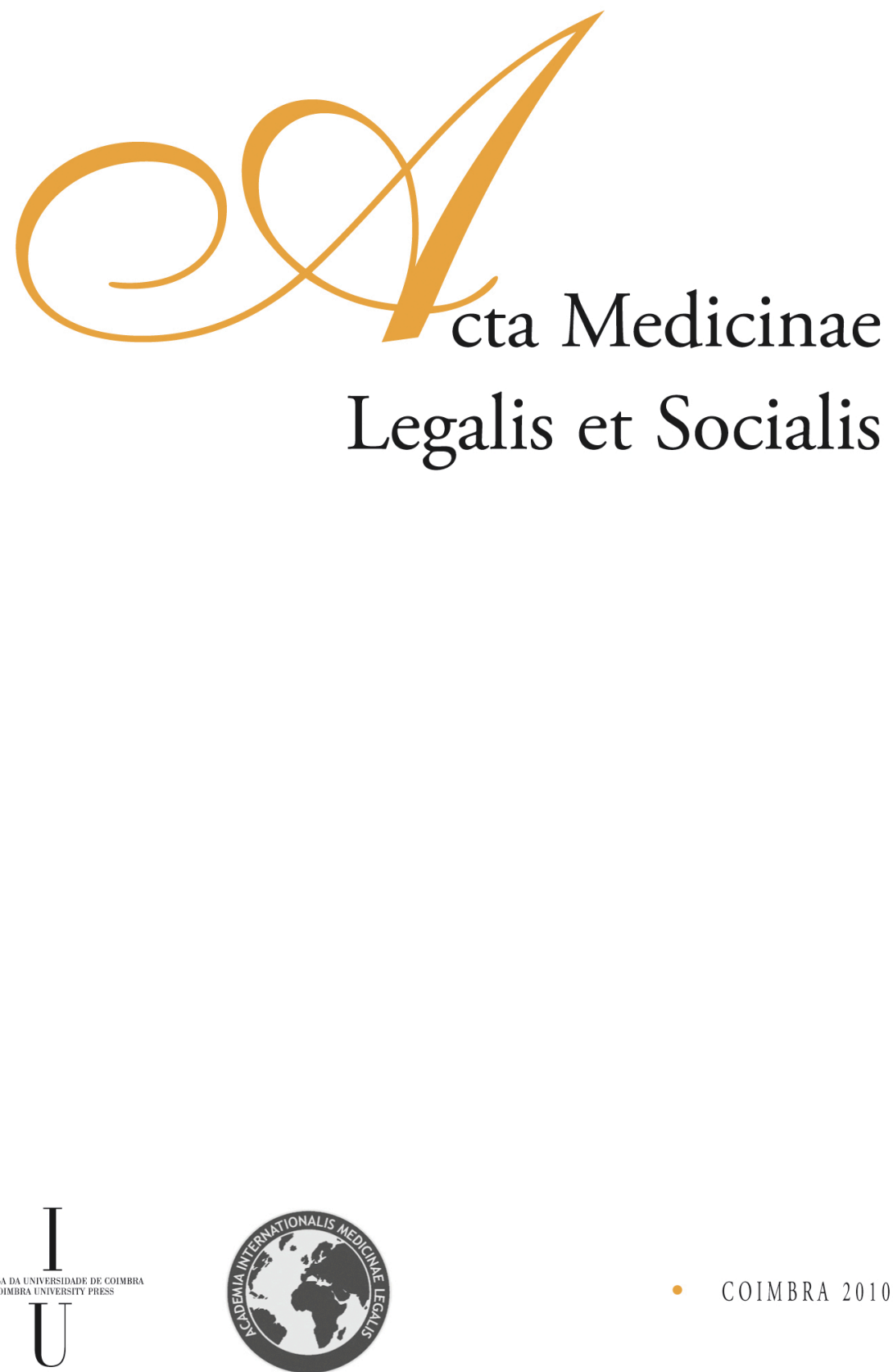


\title{
J. Redondo ${ }^{1}$
}

Psychiatrist at Coimbra Psychiatric Hospital Center (Director of the Family Violence Department), Coimbra, Portugal

\section{DOMESTIC VIOLENCE AND FORENSIC ASSESSMENT: A MULTIDISCIPLINARY NETWORK PERSPECTIVE ON THE DOMAIN OF PSYCHOLOGICAL VIOLENCE IN CONJUGALITY - PART 2}

\begin{abstract}
This paper discusses the strategy adopted by the Family Violence Department (FVD) of the Coimbra Psychiatric Hospital Center, towards the forensic assessment requested by the Investigation and Prosecution Department of Coimbra (DIAP) due to intimate partner violence (IPV) associated with psychological violence. In accordance with the National Institute of Legal Medicine (Coimbra Delegation), we are often requested to "produce a report in order to establish the psychological status of the victim and the contribution of the accused, by establishing a causal link, if possible". With the purpose of trying to provide answers to the questions made by the Justice Department to the Health Department, five integrated levels of knowledge are proposed in this paper. It is in the crossroad of the forthcoming narratives of these theories that some of the questions by DIAP can be answered.
\end{abstract}

In the past, researchers considered psychological abuse, in a domestic violence context, to be a consequence of other forms of abuse, particularly physical or sexual abuse. Now, however, psychological abuse is understood as a separate and distinct form of abuse and researchers have confirmed that it represents a common and significant form of interpersonal violence in terms of its frequency, and its short and long-term effects (Psychological Abuse: A Discussion Paper. Ottawa: Public Health Agency of Canada, 2008)

The changes caused by trauma can occur on a conscious or unconscious level. They may cause behavioural modifications, or impact on the emotional, cognitive or relational fields; so that by its quality and/or amount of events, they are experienced as a traumatic consequence that exceeds the victim's tolerance, producing a breakdown of their homeostasis. The slightest change in their adaptive defense system will be sufficient to produce health prejudice.

In order to help in forensic assessment in the area of psychological violence in conjugality, five integrated levels of knowledge are proposed.

\footnotetext{
${ }^{1}$ Correspondence concerning this article should be addressed to armejoao@netcabo.pt.
} 


\section{A theory about intimate partner violence}

Violence in general. The types of violence proposed by World Health Organization divides violence into three broad categories according to characteristics of those committing the violent act. (SLIDE 1). Family and Intimate Partner Violence ${ }^{2}$, includes forms of violence such as child abuse, intimate partner violence and abuse of the elderly.

For the purposes of this paper the term Intimate Partner Violence or Domestic Violence will be used when referring to the abuse that occurs between two people in a close relationship.

Intimate Partner Violence (IPV). One of the most common forms of violence against women is that performed by a husband or an intimate male partner. This is in stark contrast to the situation for men, who in general are much more likely to be attacked by a stranger or acquaintance than by someone within their close circle of relationships. Research suggests that physical violence in intimate relationships is often accompanied by psychological abuse, and in one-third to over one-half of cases by sexual abuse (WHO, 2002).

Although international studies have focused on physical violence because it is more easily conceptualized and measured, qualitative studies suggest that some women find the psychological abuse and degradation even more intolerable than the physical violence. As most survivors of partner abuse report, the physical violence is the least damaging abuse they suffer: it is the relentless psychological abuse that cripples and isolates the women. Accordingly Hegarty, et al (2006) from a health perspective, IPV, can be better understood as a chronic syndrome that is characterized not by the episodes of physical violence that punctuate the problem but by the emotional and psychological abuse that the perpetrator uses to maintain control over the partner.

Risk factors for IPV. We need to understand the multiciplity of risk factors that contribute to man's violence against women, so that we can appropriately target interventional programs for men and couples. Violence is the result of the complex interplay of individual, relationship, social, cultural and environmental factors. Understanding how these factors are related to violence is one of the important steps for public health approach to prevent violence. Ecological model (SLIDE 2), first introduced in the late 1970s, may aid us to understand the multifaceted nature of violence. The model explores the relationship between individual and contextual factors and considers violence as the product of multiple levels of influence on behaviour. Studies to advance the understanding of violence are needed on a variety of levels. (SLIDE 3)

The consequences of intimate partner violence. A growing body of research evidence is revealing that sharing her life with an abusive partner can have a profound impact on a woman's health (SLIDE 4). Although violence can have direct health consequences, such as injury, being a victim of violence also increases a woman's risk of future ill health. Given the long-term impact of violence on women's health, women who have suffered abuse are more likely to be long-term users of health services, thereby increasing health care costs and it does appear to influence a woman's earnings and her ability to keep a job (WHO 2002).

\footnotetext{
${ }^{2}$ Violence largely between family members and intimate partners, usually, though not exclusively, taking place in the home (WHO 2002).
} 


\section{A theory about trauma}

When trauma hits, the patterns and structures of self-organization that were there, whether in childhood or as an adult, become frozen in time. Personal assumptions of safety and connection are shaken at their roots. Strong defenses form against such terror and pain. Survival modes of living become locked into "trauma bubbles" in the face of life-threatening experiences and continue to be practiced unconsciously many years after trauma ends. Brains affected by trauma are unable to put meaning to unprocessed experiences. These fragmented memories are stored in the right brain and organized around affect, not words. In the past years, research in neurobiology shows that flashbacks and body memories, common postraumatic stress disorder symptoms, activate the emotional but not cognitive parts of the brain. Is also showing physical, measurable, biochemical changes in the brain of people who have experienced trauma. "Body remembers what the mind forgets". (Hudgins, 2002)

\section{A theory about strategies and instruments associated with the information collected}

The life history of the victims and aggressors - including their violence history, personal and developmental history, family history, socio-professional history and their clinical history (SLIDE 5) - is essential for a more precise knowledge of the histories of the associated problems and needs. Accordingly, we are developing in the Family Violence Department (SLIDE 6) a protocol to collect information to allow a more precise elaboration of the diagnosis of the situation (e.g. risk assessment, potential for changing, clinical diagnosis) and to help define an interventional strategy - more appropriate to the realistic needs of each case - as well as a prognosis. In relation to the aggressor personality assessment, we sometimes complement the evaluation carried out in the interviews with the application of the Minnesota Multiphasic Personality Inventory.

Taking into account that violence should be understood as a network phenomenon - where each violence history reflects the crossroads of life stories of the "actors" involved in the problem of violence and the many subsystems that interact with them during their life cycle - elements of primary networks (relatives and friends) and secondary network (professionals of institutions involved) are also called on to participate in the elaboration of that history. The participation of these supportive networks also represents an important contribution to the attempt of evaluating a "before" and an "after" to the event of illness in the personnel's victim's history and its eventual relation with the history of violence.

Preceding the interview and evaluation with these networks, we carry out with both, together or separately (depending on the relationship quality level and the couple's risk of retaliation), the Genogram and the Personal Social Network Map (SLIDE 7).

4. A theory about network support in relation to the emergence of narratives about families and individual histories, also of violence, and the development of a multidisciplinary and multisectorial intervention.

The personal social network includes all those with whom the individual interacts and that distinguish him from the anonymous mass of the society. The network's 
narratives is the field of histories that are common to a family or to a social network, where the focus of attention is no longer the individual, or the family, or the network as such, but histories embedded in the virtual space of the conversation between people, that is, the narrative.

Working with networks of victims and perpetrators, allows us the access to several "actors" and narratives.

In evaluating, for example, how the primary network builds its narrative around IPV, we can observe the group's structure and dynamic relationship, how this group is structured in a moment of stress, its adaptation to the life cycle, loyalties, alliances, recurrence patterns and how they deal with family secrets and myths. These provide support for the construction of narratives, where inevitably the existence of violence will emerge. Extending the assessment to the services' network gives access to the various stories that define the relationship between victims and perpetrators with those services. This approach will increase even more the probabilities of us knowing other narratives about IPV.

Adopting more holistic frameworks that integrate different approaches enables us to address abuse at the individual and societal level and to better account the diverse and complex factors associated with psychological abuse. The existing connections between the FVD and the Violence: Information, Investigation and Intervention group (SLIDE 8) - a multidisciplinary and multisectorial care network in the domestic violence area, in Coimbra - has given a strong contribution in order to offer to those who use these services more quicker and efficient answers, improved accessibility, continuity and personalization of care, along with revictimization prevention. All those aspects constitute globally important strategies in order to help diminish tensions and gain the confidence of the users of this care system.

\section{A theory about forensic assessment and the importance of a concomitant support/ therapeutic intervention}

To evaluate the situation with victims and aggressors, in conjunction with forensic evaluation, in order to define a concomitant support/therapeutic intervention at the FVD, seems a strategy with noticeable benefits to both parties. It allows, on the first stage, aside with risk assessment, revictimizing prevention and evaluation of the clinical-social situation, to soften the tension, also associated with the social visibility of the problem and the services intervention on "family matters".

After the first 3 to 4 sessions, the subsequent system extension to other relatives and friends (most of the times, with the victim's acceptance, and in several cases with the aggressors resistance), will contribute to other perceptions and perspectives of the problem as well as to enlarge its "visibility".

In several cases, the aggressor and the victim continue on the FVD, following the treatment that had been previously defined, after the judicial measure enforcement or the process suspension. It is relevant to underline that some of the aggressors, which abandon the Violence Family Department earlier, suffer from personality disorders and end up separated or divorced from the victim. 
On a global perspective, such a joint intervention is assuring and protective of the victim and it increases a more effective "visibility" of the violence (since the evaluation occurs on a most relaxed environment). In this change, the support networks also plays an important role, which usually accepts positively the idea of both, the victim and the aggressor, being followed up by a specific service in the family violence field.

\section{Final considerations}

The richness and complexity of the relationship between traumatic experiences, the many variables that influence the response to these experiences and the symptoms and syndromes that are associated represent a serious obstacle to its "visibility".

In the trauma investigation field, it is essential to have a knowledge of the related theories. It is important to understand and to know how to assess the answers to traumatic experiences, and to have the appropriate methods to validate the impact of the trauma, along with an effective and efficient clinical practice in treating traumatized people. The non-revictimization of those who suffer is a central aspect of this area of investigation. It is imperative to maximize the accuracy of assessments and minimize the effects on the victims.

In this framework, and with the aim of a most effective evaluation of psychological damage, it is essential, along with the previously mentioned, to continue to pursue the development of a matrix, both in the theoretical and conceptual framework of the issues in analysis, along with the integration and standardization of appropriate tools and strategies for correct analyzing and understanding of the problem (e.g. specific evaluation tools, protocols).

It is also important to enhance the importance of invisibility of the psychological damage in the legal and health speeches, taking into account the severity of this problem's impact in the quality of life of those who suffer.

Given the many problems related to domestic violence it is fundamental to create a care structure or organization - focus on multidisciplinary, multisectoral and network's intervention - along with the investment, in partnership with the Legal Medicine, on a research project in order to improve the gathering of evidence within the psychological violence in marriage.

\section{References}

HARWAY, M, O'NEIL, J.M. (Eds.). What causes men's violence against women? Thousand Oaks, CA: Sage Publications, 1999.

KRUG E.G., DAHLBERG L.L., MERCY J.A., ZWI A.B., LOZANO R (Eds.). World report on violence and health. Geneva, Switzerland: World Health Organization, 2002.

HUDGINS, M. KATHERINE. Experiential Treatment for PTSD: The Therapeutic Spiral Model. New York: Springer, 2002.

HEGARTY K, ROBERTS G, FEDER G (Eds.). Intimate partner abuse and health professionals: new approaches to domestic violence. Edinburgh: Churchill Livingstone, 2006.

Canada. National Clearinghouse on Family Violence. Psychological Abuse: A Discussion Paper. Prepared by Deborah Doherty and Dorothy Berglund. Ottawa: Public Health Agency of Canada, 2008. 


\section{Violence typology}

The World Health Organization defines violence as "The Intentional use of physical force or power, threatened or actual, against oneself, another person, or against a group or community, that either results in or has a high likelihood of resulting in injury, death, psychological harm, maldevelopment or deprivation" (WHO, 2002)

WHO, “World Report on Violence and Health" (2002)

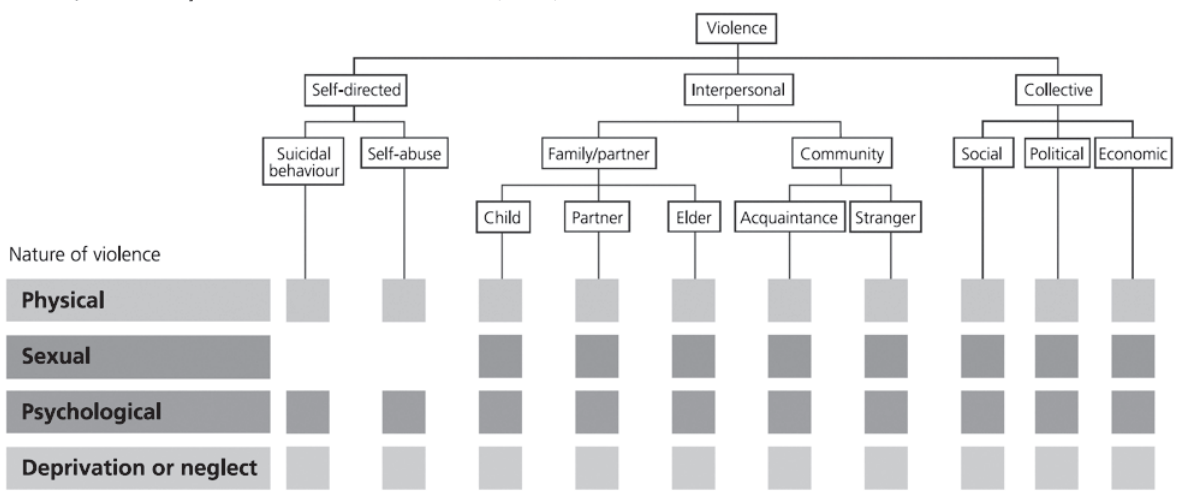

Intimate partner violence refers to any behaviour within an intimate relationship that causes physical, psychological or sexual harm to those in the relationship. Occurs in all countries, irrespective of social, economic, religious or cultural group.

Initially viewed largely as a human rights issue, partner violence is increasingly seen as an important public health problem

\section{Ecological Model}

(...) The model explores the relationship between individual and contextual factors and considers violence as the product of multiple levels of influence on behaviour.

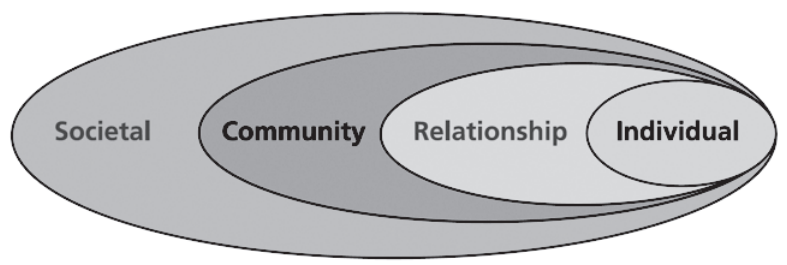

Factors associated with man's risk for abusing his partner

\begin{tabular}{llll}
\hline Individual factors & Relationship factors & Community factors & Societal factors \\
\hline - Young age & - Marital conflict & - Weak community sanctions & - Traditional gender norms \\
- Heavy drinking & - Marital instability & against domestic violence & - Social norms supportive of \\
- Depression & - Male dominance in the family & - Poverty & violence \\
- Personality disorders & - Economic stress & - Low social capital & \\
- Low academic achievement & - Poor family functioning & \\
- Low income & & \\
- Witnessing or experiencing & & \\
violence as a child & & \\
\hline
\end{tabular}

WHO, "World Report on Violence and Health" (2002)

Slide - 2 


\section{A Revised Multivariate Model Explaining Men's Risk For Violence Against Women (Harway \& O'Neil, 1999)}
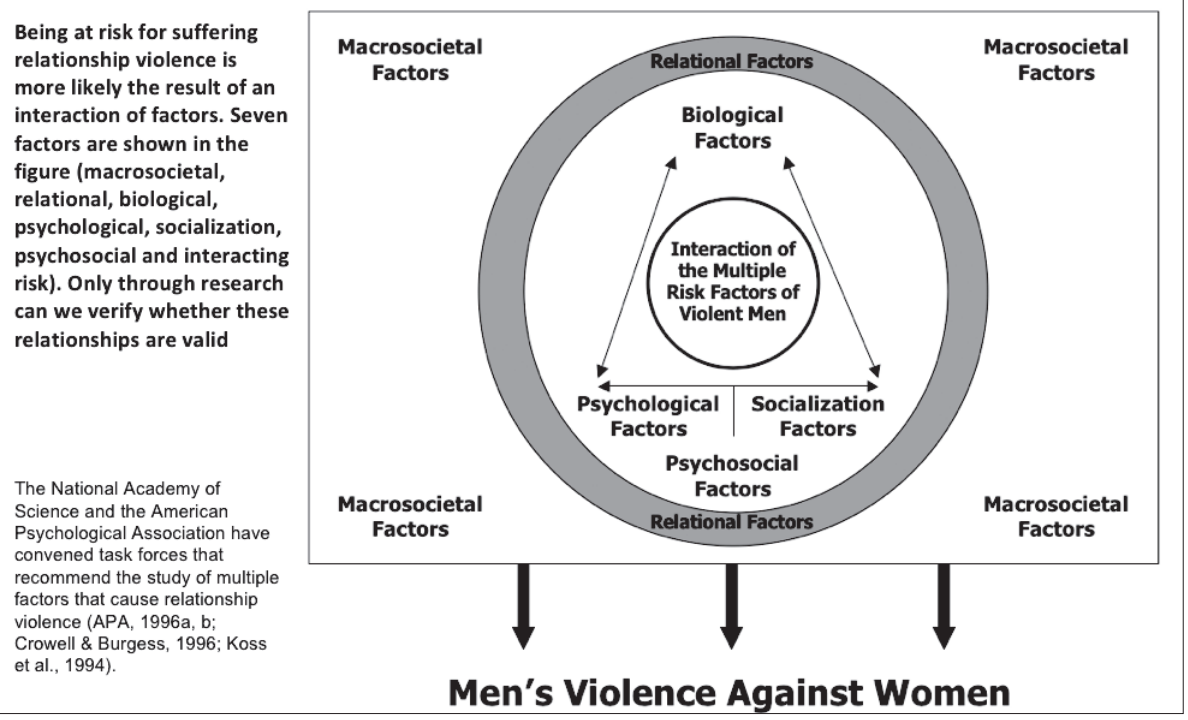

Slide -3

\section{Health Consequences of Intimate Partner Violence}

"In general, the following are conclusions emerging from current research about the health consequences of abuse:

- The influence of abuse can persist long after the abuse itself has stopped

- The more severe the abuse, the greater its impact on a woman's physical and mental health

- The impact over time of different types of abuse and of multiple episodes of abuse appears to be cumulative" (WHO, 2002)

Fatal health consequences AIDS-related mortality

Maternal mortality

Homicide

Suicide

\section{Sexual and reproductive}

Gynaecological disorders

Infertility

Pelvic inflammatory disease

Pregnancy complications/miscarriage

Sexual dysfunction

Sexually transmitted diseases, including HIVIAIDS

Unsafe abortion

Unwanted pregnancy
Psychological and behavioural

Alcohol and drug abuse

Depression and anxiety

Eating and sleep disorders

Feelings of shame and guilt

Phobias and panic disorder

Physical inactivity

Poor self-esteem

Post-traumatic stress disorder

Psychosomatic disorders

Smoking

Suicidal behaviour and self-harm

Unsafe sexual behaviour
Physical

Abdominal/thoracic injuries

Bruises and welts

Chronic pain syndromes

Disability

Fibromyalgia

Fractures

Gastrointestinal disorders Irritable bowel syndrome Lacerations and abrasions Ocular damage

Reduced physical functioning

WHO, “World Report on Violence and Health" (2002) 


\section{Possible}

\section{Indicators of}

\section{Psychological}

\section{Abuse}

The effects of psychological abuse can be manifested in many different forms and may be difficult to detect. The abuse does not leave physical markings, but it does have substantial, and often long-lasting, impacts on the victim that may escalate or transform over the lifespan

* Indicators of PTSD include haunting memories, nightmares, social withdrawal, anxiety, depression, sleep disturbances, fatigue, difficulty concentrating, memory loss, and feelings of helplessness, fear and ange (Meyers 2004).

(Canada. National Clearinghouse on Family Vlolence. Psychological Abuse: A Discussion Paper. Ottawa: Public Health Agency of Canada, 2008)

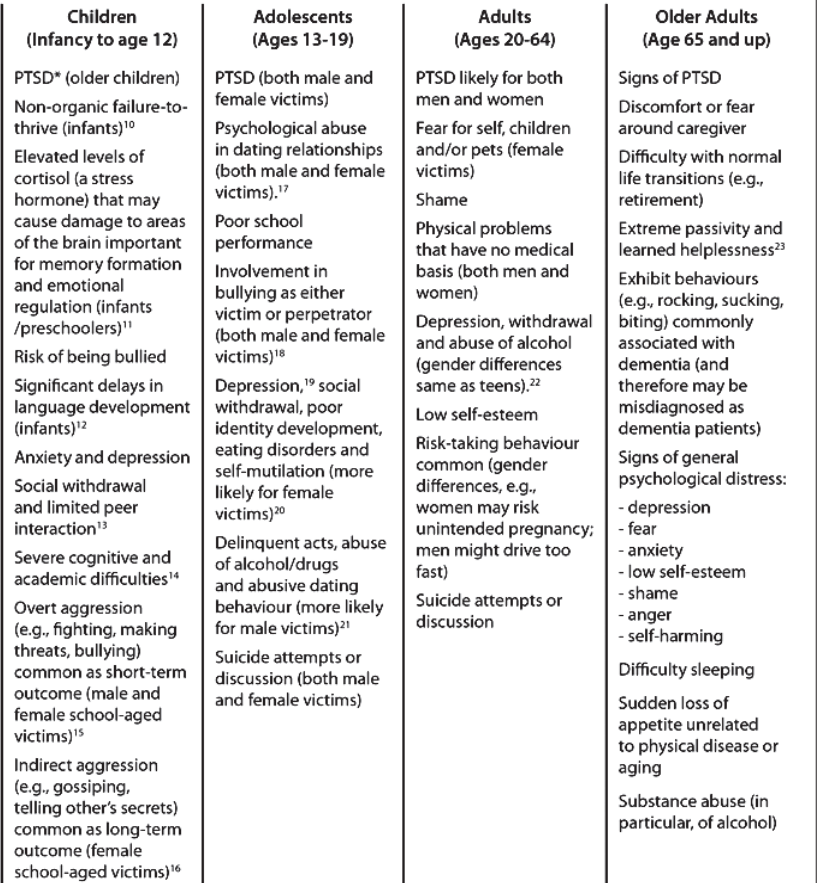

Slide - 5

\section{Family Violence Department CHPC - Sobral Cid}

A.P.A.V. - PRIMARY CARE

- C.P.C.J.

- D.G.R.S.

- E.M.A.T.

- FAMILY

- F.B.Barreto

- HOSPITALS

- JUSTICE DEPARTMENT

- LINE 144

- P.S.P.

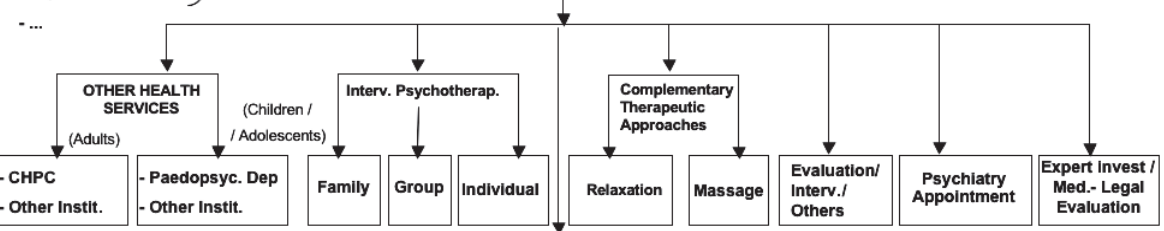

Other Instit. Other Instit.

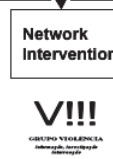

JoInt Evaluation - SFV, DGRS, DIAP - SFV, EMAT, TFM SVF, CPCJ Coimbr

Slide -6 


\section{Genogram}

The genogram is an analytical tool which enables one to visualize the family structure and to allow assessment of individual, interactional, and intergenerational patterns within family systems. Includes at least three generations of family members

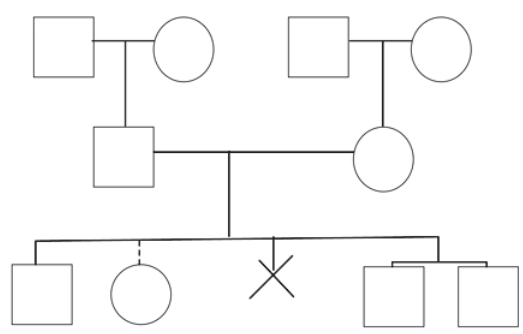

\section{Personal Social Network Map}

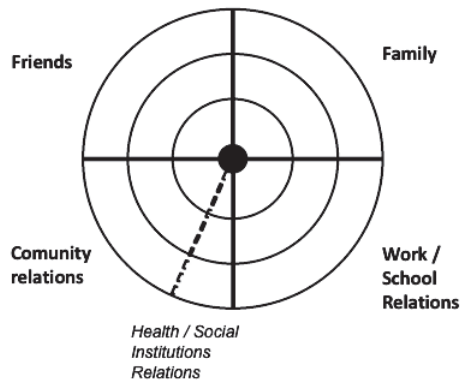

Our personal social network - that rather stable but continually evolving interpersonal fabric constituted by close and distant family members, friends, work and study connections, and relationships that result from informal and formal participation in community organizations (religious, social, political, healthrelated, etc.) - constitutes a key depository of our identity, our history and our well being (Sluzki, 1996)
Reglonal Health Administration - Centre (ARSC)

Dr. Fernando Gomes (Family Doctor); Dr. M José Hespanha (Family Doctor)

Reglonal Institute of Solidarity and Social Security - District of Colmbra Dr. Emilla Santos (Social Assistant); Dr. Anabela Rodrigues (Social Assistant)

Colmbra Hospital Centre (CHC)

- Department of Child and Adolescent Psychlatry

Dr. Beatriz Pena (Paedopsychiatrist; Dr. Anabela Fazendeiro (Psychologist)

- Emergency Department of the General Hospital

Dr. Maria Joāo Frade (Neurosurgeon)

Investigation and Penal Action Department - Colmbra (DIAP) Dr. Paula Garcia (Public Prosecutor)

Faculty of Psychology and Education - University of Coimbra Ph. D. Madalena Alarcão (Psychologist)

Bissaya Barreto Foundation

Dr. Fátima Mota (Social Assistant)

Portuguese Association for Victim Support (APAV) - Coimbra Dr. Natália Cardoso (Jurist); Dr. Sonia Santos (Psychologist)

Colmbra Psychlatric Hospital Centre (CHPC)

Dr. Joâo Redondo (Psychiatrist); Dr. Luisa Rosa (Psychiatrist)

Coimbra Delegation of the National Institute of Legal Medicine Dr. Rosário Lemos (Forensic Doctor)

National Institute for Medical Emergencies (INEM) Dr. Sara Rosado (Psychologist)

Public Safety Police - Coimbra

Manuel Jesus (Chief); Graça Tejo (Agent)
VIOLENCE:

INFORMATION

INVESTIGATION

INTERVENTION

www.violencia.online.pt

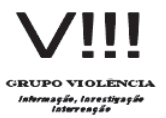

In a NETWORK it is important

that everyone knows everything

that everyone is equally responsible

ensure transparency

Slide -8 